\title{
Physiological Panel of Some Feed Additives for Turkey Toms
}

\author{
Sohair Y. Saleh ${ }^{1}$, N. S. El-Toukhy ${ }^{1}$, H. I. Abass ${ }^{1}$, S. I. El-Samannoudy ${ }^{1}$, M. A. Tony ${ }^{2}$ \& A. M. Hassanin ${ }^{3}$ \\ ${ }^{1}$ Department of Physiology, Faculty of Veterinary Medicine, Cairo University, Giza, Egypt \\ ${ }^{2}$ Department of Nutrition and Clinical Nutrition, Faculty of Veterinary Medicine, Cairo University, Giza, Egypt \\ ${ }^{3}$ Department of Cytology and Histology, Faculty of Veterinary Medicine, University of Sadat City, Meonofya, \\ Egypt \\ Correspondence: Sohair Y. Saleh, Department of Physiology, Faculty of Veterinary Medicine, Cairo University, \\ Giza 12211, Egypt. Tel: 202-3748-7239. E-mail: sohair_saleh@hotmail.com
}

Received: October 6, 2017

doi:10.5539/jas.v9n12p335

\author{
Accepted: November 8, $2017 \quad$ Online Published: November 15, 2017 \\ URL: https://doi.org/10.5539/jas.v9n12p335
}

\begin{abstract}
A tolerance test was conducted with total 48 male turkeys (strain, Big 6, of three months old) over a period of 70 days, to find the effect of basil and thyme (medicinal plants) and some enzymes (kemzyme and zymogen) as feed additives on turkey toms' performances. Forty-eight male turkeys ( 3 months old) were randomly divided into eight groups (6 toms/each). The control group (C) was fed a basal diet without feed supplementation. Group (B) was supplemented with basil ( $3 \mathrm{~g}$ basil/ $\mathrm{kg}$ diet) group (T) was fed thyme ( $2 \mathrm{~g}$ thyme/kg diet), group (TB) was fed a mixture of basil and thyme ( $3 \mathrm{~g}$ basil $+2 \mathrm{~g}$ thyme $\mathrm{kg}$ diet), group $(\mathrm{Z})$ was fed zymogen $(1 \mathrm{ml} / 4$ liter water); and group (K) was supplemented with kemzyme $(0.5 \mathrm{~g} / \mathrm{kg}$ diet), group (BTK) was fed a mixture of basil, thyme and kemzyme, the last group was fed with diet supplemented with basil, thyme and zymogen. Body weight gain, feed conversion ratio was measured at the end of $10^{\text {th }}$ week of experiment. Blood samples were taken to measure some biochemical parameters, at the same time some tissues for morphological and molecular studies were prepared. Toms fed with either basil, thyme or kemzyme $(B T)$ had significantly $(p<0.05)$ heaviest body gain than the control, (Z) or (BTZ). Significant increase occurred of the dressing percent (DP\%) in group (B) and (BT) compared to the groups (T, Z, BTK and BTZ).

Supplementation with $(\mathrm{K})$ significantly decreases the serum total lipids than the $(\mathrm{C})$ group and all supplemented groups at $\mathrm{P}<0.05$. Serum cholesterol levels of the groups (T), (BT) and $(\mathrm{Z})$ recorded a significant increase than those of groups (C), (K), (BTK) and (BTZ). Meanwhile; triglyceride levels revealed significant decrease in control group at $(p<0.05)$ than all other groups. All experimental groups recorded no differences in both serum protein and albumin. Although there were an increased levels of serum AST of groups (T) and (Z) compared to control and other groups, meanwhile; (T) and (Z) groups revealed the lowest level of serum ALT.

Concerning the antioxidant parameters, results reviewed that (T), (BT), (BTK) and (BTZ) had a higher level of MDA activity than the (B), (K) and (Z) supplemented groups illustrate no difference versus the serum (MDA) activity of the $(C)$ group. Serum SOD activity revealed no differences within all groups. Serum TAC recorded significant increase in all supplemented groups compared to their level in control group.

Studies of intestinal integrity; morphometry studies indicated that the villous height increased in groups (T), (Z) and (BTK) with a higher villous to crypt ratio and goblet cell numbers of group supplemented with (BTK). Moreover, the villous width revealed a significant increase in the (C) and (Z) groups. The measurement of total DNA of duodenal tissues which reflect the cell mitosis was higher in (T), (Z) and (BTK), (BTZ) at P $<0.05$; the recorded results of DNA/protein of the same segment of the duodenal tissues revealed higher ratio (higher ribosomal activity) of (T), (Z), and (BTK) groups. Cell size of the duodenal tissues as indicated by (protein/DNA) was increased by $(K)$ and decrease by $(T)$ and $(Z)$ supplementation at $\mathrm{P}<0.05$.
\end{abstract}

Keywords: basil, kemzyme, thyme, turkey, zymogen

\section{Introduction}

The use of some antibiotics as growth promoters creates a huge problem for environmental condition and health of consumers around the world (Houshmand et al., 2011; Toghyani et al., 2010). Therefore, there has been growing interest in developing natural alternatives to antibiotic growth promotersin order to maintain both 
performance and health (Khan et al., 2012). Consequently, Peric et al. (2010) reported that some natural substances which would influence improvement of health and production traits of broiler chicken can be used such as herbs, enzymes, antioxidants, plant extracts and medicinal and aromatic plants.

The herbs and plant extracts used as feed additives include many different bioactive ingredients such as alkaloids, bitters, flavonoids, glucosides, mucilage, saponin and tannins (Wenk, 2000; Zheng \& Wang, 2001). Therefore, the expected effects of herbs and plant extracts are also various, the herbs and plant extracts act on appetite and on intestinal microflora, stimulate pancreatic secretions to increase endogenous enzyme activity and immune system. Many plant products and their constituents have a broad antimicrobial and antioxidant properties. Besides scientists discovered that appetizing and stimulating activity of herbs and plant extracts on animal digestive and immune system could benefit performance and health of poultry (Galinish \& Halle, 2000; Tucker 2002; Osman et al., 2010) they postulated the effect could be due to improvement of absorption and utilization of digestive products. Moreover, Abdel-Azeem (2006) and Osman et al. (2005) reported that using medicinal and aromatic plants in broiler diets improved body weight, body weight gain and reduce the cost of feed. Other scientific evidence proved that many herbs and their bioactive constituent possess broad antimicrobial activities which in turn minimize pathogenic bacteria activity in the gastrointestinal tract (Laughout, 2000; Lewis et al., 2003).

The use of enzymes in the feed of animals particularly poultry has become more common (Saleh et al., 2010; Ahmed et al., 2013). Exogenous feed enzymes have been shown to improve performance and nutrient digestibility (Taylor-Pickard \& Spring, 2008). In addition Olukosi et al. (2007) found enzymes to be effective in improving growth performance especially at early age. The benefits of adding commercial enzymes preparation to poultry feed have been researched extensively in broiler. Odetallah et al. (2002) reported that adverse effects induced as a result of NSPS complex including the formation of viscous mucus, when fully hydrated and the consequent impedance of nutrient absorption from chyme which cause reduced growth performance, can be alleviated by appropriate enzyme supplementation. Supplementing endoxylanse and $\beta$ glucanase enzyme mixture to wheat-based diet, significantly improved body weight gain and reduce viscosity of digesta of small intestine, increase growth performance in growing turkey toms (Mathlouthi et al., 2003). Little information is available about the benefits of adding herbs and multienzymes to turkey tom breeder diets. Therefore the present study was designed to investigate the benefits of adding basil, thyme and their combination on some productive performances, integrity and functionality of gastrointestinal tract, Evaluate enzymes as additives (amylase, protease and xylanase) in the form of kemzyme/ration or zymogen/water and compare between a mixture of (basil, thyme and kemzyme) (BTK) and (basil, thyme and zymogen) (BTZ).

\section{Material and Methods}

\subsection{Birds and Location}

The present study was carried out at Animal and Poultry Management center, Faculty of Veterinary Medicine, Cairo University, Egypt. The experiment lasted for 10 weeks, during the period from March till May 2015.

Forty eight male turkey toms of Big six breed three months old, with an average body weight $5.5 \mathrm{~kg}$ were divided into eight groups of six toms each, they were treated as follow: the control group (C) was fed a basal diet without supplementation, group (B) was supplemented with basil ( $3 \mathrm{~g} / \mathrm{kg}$ diet), group (T) was fed Thyme ( $2 \mathrm{~g} / \mathrm{kg}$ diet), group (BT) was fed a mixture of basil and thyme ( $3 \mathrm{~g}$ basil $+2 \mathrm{~g}$ thyme/kg diet), group (Z) was fed zymogen $(1 \mathrm{ml} / 4 \mathrm{~L}$ water), group $(\mathrm{K})$ was supplemented with kemzyme $(0.5 \mathrm{~g} / \mathrm{kg}$ diet), group (BTK) was fed a mixture of basil, thyme and kemzyme and the last group (BTZ) was fed diet supplemented with basil, thyme and zymogen. Each group was kept individual cage with lighting regimen 23 hours light daily (Prescott et al., 2003).

\subsection{Feed Additives}

Basil: Natural feed additive, its main constituents are methyl chavicol, eugenol, linalool, camphor and methyl cinnamate. It is obtained from Haraz spice shop Egypt.

Thyme: Natural feed additives, its main constituents are thymol, carvacrol, linalool and Caffeic acid. It is obtained from Haraz spice shop Egypt.

Zymogen: Amultienzyme feed additive composed of amylase, protease, lipase, cellulase, xylanase and pectinase it was a gift from United Biomed Company-Egypt.

Kemzyme: A multienzyme feed additive containing protease, $\alpha$-amylase, $\beta$-glucanase, cellulose, amylase and lipase produced by Kemin industry and provided as a gift from United Biomed Company-Egypt. 


\subsection{Feed}

Basal ration were formulated to cover the nutrient requirements of growing turkey according to National Research Center (NRC) (1994).

The composition of the formulated diet is shown in Table 1, then the additives were added according to the group:

Table 1. Composition percentage and calculated nutrients profile of the basal diets

\begin{tabular}{lllll}
\hline \multirow{2}{*}{ Ingredients \% } & \multicolumn{3}{c}{ Age (weeks) } \\
\cline { 2 - 5 } & $8-12$ & $13-17$ & $18-21$ & $22-24$ \\
\hline Yellow corn & 49.336 & 59.262 & 68.766 & 75.353 \\
gluten meal & 5.657 & 4.358 & 3.227 & 2.467 \\
Soybean meal (44\% CP) & 38.426 & 29.598 & 21.917 & 16.758 \\
Soy oil & 2.176 & 2.326 & 2.10 & 1.169 \\
Dicalcium phosphate & 2.273 & 2.074 & 2.153 & 2.21 \\
Limestone & 1.162 & 1.383 & 0.788 & 0.795 \\
Common salt & 0.298 & 0.30 & 0.30 & 0.30 \\
DL Methionine & 0.142 & 0.148 & 0.196 & 0.229 \\
L-Lysin & 0.230 & 0.251 & 0.253 & 0.419 \\
Vitamin \& mineral premix* & 0.30 & 0.30 & 0.30 & 0.30 \\
\hline Calculated Analysis** & & & \\
ME (Kcal/kg) & & 3000 & 3085 & 3100.62 \\
Crude Protein\% & 2906.43 & 20.00 & 17.00 & 15.01 \\
Calcium\% & 24.02 & 1.13 & 0.90 & 0.90 \\
Non-phytate phosphorus\% & 1.12 & 0.50 & 0.50 & 0.50 \\
Methionine\% & 0.55 & 0.50 & 0.50 & 0.50 \\
Lysine\% & 0.55 & 1.00 & 1.00 & 1.00 \\
Meth. + Cyst.\% & 1.40 & 0.85 & 0.80 & 0.77 \\
\hline
\end{tabular}

Note. * Per kg premix: $10000000 \mathrm{IU}$ vit. A, $1000000 \mathrm{IU}$ vit. $\mathrm{D}_{3}, 50000 \mathrm{mg}$ vit. $\mathrm{E}, 7000 \mathrm{mg}$ vit. $\mathrm{K}_{3}, 2000 \mathrm{mg}$ vit. $B_{1}, 6000 \mathrm{mg}$ vit. $B_{2}, 2000 \mathrm{mg}$ vit. $\mathrm{B}_{6}, 25 \mathrm{mg}$ vit. $\mathrm{B}_{12}, 50000 \mathrm{mg}$ niacin, $220 \mathrm{mg}$ biotin, $15000 \mathrm{mg}$ folic acid, $400000 \mathrm{mg}$ choline, $2000 \mathrm{mg}$ pantothenic acid, $400000 \mathrm{mg}$ magnesium, $70000 \mathrm{mg}$ zinc, $30000 \mathrm{mg}$ manganese, $75000 \mathrm{mg}$ iron, $5000 \mathrm{mg}$ copper, $750 \mathrm{mg}$ iodine and $250 \mathrm{mg}$ cobalt.

** Calculated analysis was based on National Research Center (NRC) (1994).

\subsection{Measured Parameters}

\subsubsection{Growth Parameter}

The live body weight of turkey toms was recorded at the beginning of the experiment ( 3 month age), he weekly changes and daily feed consumption calculated till the end of the experiment (at the end of the $10^{\text {th }}$ week) to compute the following: Average daily feed intake, average daily body weight gain (g/week), feed efficiency and feed conversion ratio.

\subsubsection{Serum Biochemical Parameter}

All tests were performed using kits purchased from Spectrum Company, Dokki, Giza, Egypt. Cholesterol was estimated according to Ellefson and Carawy (1976), triglycerides according to (Bucolo \& David, 1973), Total lipids estimated according to (Zollner \& Kirsch, 1962), total protein method by (Kaplan and Szalbo, 1983), Albumin was measured according to method of (Grant et al., 1987), alanine amino transferase and asprtate amino transferase were estimated according to (Breuer, 1996).

Antioxidant parameters such as malonaldehyde (MDA), serum oxide dismutase (SOD) were performed using kits purchased from Biodiagnostic Company, Dokki, Egypt according to method by Ohkawa et al. (1979), (Nishikimi et al., 1972) respectively and total antioxidant capacity (TAC) according to (Koracevic et al., 2001).

\subsubsection{Intestinal Morphometry}

At the end of experiment samples from duodenum taken for measuring the length and width of intestinal villi, depth of crypts and number of goblet cells using light microscope according to (Brancroft et al., 1996). 


\subsubsection{Intestinal Integrity}

DNA and RNA purification from tissues (QIA amp DNA, RNA min kit) were applied according to (Fisher \& Suttle, 2011).

\subsection{Statistical Analysis}

Data are represented as means and analyzed by one-way ANOVA using Microsoft office excel computer program excel version 2007 according to (Snedecor \& Cochran, 1980). The groups were compared by pooled standard error (SE pooled) at P value $\leq 0.05$ ) (Bret Larget, 2003).

\section{Results and Discussion}

The present study was conducted to clear the turkey gastrointestinal tract integrity and functionality using feed additives basil (B), thyme (T), kemzyme (K) and zymogen (Z). Most of published research has dealt with growth performance without looking to the integrity of intestinal tract and metabolic parameters. Moreover, the panel of combination of natural medicinal plants and some enzyme endorse little attention.

The herbs and plant extract act on appetite, intestinal microflora, stimulate pancreatic secretions to increase endogenous enzymes activity and immune system. Many plant products have a broad antimicrobial activity, antioxidant and sedative properties (Demir et al., 2005). They postulated that, effect could be due to increase production of digestive enzymes and improved utilization of digestive products (Laughout, 2002).

3.1 Effect of Basil, Thyme, (Basil + Thyme), Zymogen, Kemzyme, (Basil + Tyme + Kemzyme) and (Basil + Thyme + Zymogen on Body Weight (BWt/Kg), Body Weight Gain (BWG/g), Feed Efficiency (FE) and Feed Conversion Ratio (FCR) of Turkey Toms

The results presented in Table 2 indicates that, the body weight (BWt), dressing percentage (D.P.) and both feed efficiency (FE) and feed conversion ratio (FCR) at the end of the experimental period (10 ${ }^{\text {th }}$ week). Data identify shows a significant increase in (BWt) of toms supplemented with (B) or (T) or (BT) and (K) as compared to that of (C) or (BTK) or (BTZ) groups. The former results is proud with that of Wenk (2000) and Zheng and Wang (2001) who cleared the benefits of herbs and plant like basil and thyme which include many different bioactive ingredients such as alkaloids, bitters, flavinoids, glucosoids, mucilage, saponines and tannins. As well as the results of the growth performance and feed efficiency confirm the finding of Abbas et al. (2010), Alloui et al. (2012), Iji et al. (1999), Feizi et al. (2013), Khan et al. (2012), Mamoun et al. (2014) and Osman et al. (2010), who reported that, broilers fed basil diet had significantly the heaviest body weight. While the natural medicinal plant was considered alternative to antibiotics growth promoters. Also, the results are inagreement with Sharifi et al. (2013) who suggested that herbs and various plants have appetizing and antimicrobial properties. Concerning to all finding as a growth performance and feed conversion the present results in groups supplemented with either (B) or (T), it go hand by hand with the former finding of Alloui et al. (2012) and Mamoun et al. (2014) who suggest a morphological change of a gastrointestinal tissue in broiler chicken that increase the production performance (weight gain and feed conversion).

Moreover, indirectly the increase of Body weight are proud with the evidence that herbs and plant extract stimulate the growth of beneficial bacteria and minimize pathogenic bacteria activity in the gastrointestinal tract (Laughout, 2000; Wenk, 2000). Besides that, scientists discovered appetizing and stimulating activity of herbs and plant extracts on animal digestive and immune system could benefit performance and health of poultry (Abdel Azeem, 2006; Ahmed, 2011; Osman et al., 2005; Tucker, 2002). Thus the obtained results assured the former recorded data. At the same time, the improved body weight could be attributed to the presence of thyme oil which stimulate secretion of digesting enzymes (Aji et al., 2011; Khan et al., 2010; Feizi et al., 2013). Additionally, enzyme supplementation (K) was associated with assured the finding of (Falcao-e-Cunha et al., 2007; Saleh et al., 2006, 2008) While enzyme can partially hydrolyze the non-starch polysaccharide (NSP) reduce the viscosity of gut contents and result in improvements of nutrient absorption.

Santos et al. (2004) and Zhou et al. (2009) who declared that the negative effects of intestinal viscosity due to NSP can be alleviated by exogenous enzyme like kemzyme and enhance metabolizable energy value of the diet and improved body gain. Those results are in agreement with our results concerning (K) supplementation for (BWG) and (FE).

Additionally, the increase of BWt in group supplemented by enzyme (k) declared and confirmed the finding that, the enzyme supplementation improve, digestibility and absorbability of dietary elements (Mathlouthi et al., 2003). Moreover, Margovi et al. (2001) pointed that the exogenous enzymes can survive in the intestine together with the endogenous enzymes and exert their action on available substrates. These activities could be favorable change in pH of gut mediated by exogenous enzyme (Abdl-Rahman et al., 2010). While Douglas et al. (2000) 
recorded that broiler performance was not affected by enzyme supplementation. Zakaria et al. (2010) recorded that, exogenous enzyme was not capable of modifying gastrointestinal environment to improve efficiency of feed utilization. Meanwhile Hajati (2010) found that adding enzymes to broilers diet significantly decreased body weight gain and feed intake.

Table 2. Effect of basil, thyme, (basil + thyme), zymogen, kemzyme, (basil +thyme + kemzyme) and (basil + thyme + zymogen) on body weight $(\mathrm{BW} / \mathrm{kg}$ ), body weight gain $(\mathrm{BWG} / \mathrm{g})$, Feed Efficiency (FE) and feed conversion ratio (FCR) of turkey toms

\begin{tabular}{llllllllll}
\hline \multirow{2}{*}{ Growth } & \multicolumn{9}{c}{ Group } \\
\cline { 2 - 10 } & $\mathrm{C}$ & $\mathrm{B}$ & $\mathrm{T}$ & $\mathrm{BT}$ & $\mathrm{Z}$ & $\mathrm{K}$ & $\mathrm{BTK}$ & $\mathrm{BTZ}$ & SE pooled \\
\hline BWt (kg) & 14.91 & 16.49 & 16.03 & 16.26 & 14.25 & 16.09 & 15.87 & 14.31 & 0.8 \\
BG (gm) & 1.06 & 1.19 & 1.26 & 1.42 & 1.03 & 1.32 & 1.56 & 1.12 & 0.5 \\
DP $(\%)$ & 85.30 & 86.30 & 84.30 & 86.50 & 82.80 & 85.00 & 83.30 & 81.71 & 2.1 \\
FE & 2.82 & 2.54 & 2.75 & 2.68 & 2.48 & 2.68 & 2.88 & 2.98 & 1.2 \\
FCR & 0.35 & 0.71 & 0.66 & 0.40 & 0.42 & 0.49 & 0.43 & 0.72 & 0.5 \\
\hline
\end{tabular}

Note. Data indicate mean, $\mathrm{n}=6$ /group. Control (C), basil (B), thyme (T), basil + thyme (BT), zymogen (Z), kemzyme (K), basil + thyme + kemzyme (BTK), basil + thyme + zymogen (BTZ), body weight (BWt), body weight gain (BWG), feed efficiency (FE), feed conversion (FCR), pooled standard error (SE pooled).

\subsection{Effect of Basil, Thyme, (Basil + Thyme), Zymogen, Kemzyme, (Basil + Tyme + Kemzyme) and (Basil + Thyme + Zymogen) on Some Serum Metabolic Parameters}

Data presented in Table 3 records that serum cholesterol levels were increased by supplementation with $(\mathrm{T})$ or (BT) or (Z) versus to those (C), (B), (K), (BTK) or (BTZ). Moreover, the serum triglyceride was observed to be significantly increased in all experimental groups compared to that level. The former results are in contrast to the previous records of Al-Kassie et al. (2009), Darshana and Thyagaraja (2014), Khan et al. (2011), Isa (2011), and Toghyani et al. (2010) who attributed the reduction of serum cholesterol and triglyceride to the presence of high fiber level in thyme which increased the bile excretion and thus decrease serum cholesterol level. Moreover, Mansoub et al. (2011a, 2011b) found that $1 \mathrm{gm} / \mathrm{kg}$ thyme fed to broilers resulted in improved cholesterol profiles. Also, Lee et al. (2003) found a reduction of serum cholesterol and triglyceride levels as results of thyme supplementation was due to the lowering effect of thymol and carvacrol on HMG-COH reductase which is the rate limiting enzyme of cholesterol synthesis. Meanwhile, Sengül et al. (2008) found no effect of thyme on blood cholesterol level. Also, Abbas et al. (2010) reported that basil as a feed additive for broilers resulted in a reduction for cholesterol level. Moreover, increased level of both serum triglycerides and cholesterol levels in groups supplemented with enzyme (K) or (Z) confirm the former reported data of Ahmed et al. (2013), Hajati (2010), Saleh et al. (2006), and Saleh et al. (2010).

The same table shows a significant increase of aspartate amino transferase (AST) serum activities in groups supplemented with either $(\mathrm{T})$ or $(\mathrm{Z})$. Meanwhile, both groups $(\mathrm{T})$ and $(\mathrm{Z})$ recorded a significant decrease of serum alanine amino transferase (ALT) than all other experimental groups in contrast to the results obtained by Ahmed et al. (2013) who found that supplementation of broilers ration with polyzymes did not produce changes in the activities of ALP, AST and ALT. But, these results go hand by hand with (K) group indicating that multi enzyme $(K)$ is safe does not alter hepatic function of turkey toms (Abaza \& Omara, 2011). 
Table 3. Effect of basil, thyme, (basil + thyme), zymogen, kemzyme, (basil + thyme + kemzyme) and (basil + thyme + zymogen) on some serum metabolic parameters

\begin{tabular}{llllllllll}
\hline \multirow{2}{*}{ Parameters } & \multicolumn{10}{c}{ Group } \\
\cline { 2 - 9 } & C & B & T & BT & Z & K & BTK & BTZ & SE pooled \\
\hline Cholesterol $(\mathrm{mg} / \mathrm{dl})$ & 105 & 99 & 121 & 125 & 114 & 107 & 98 & 94 & 6.7 \\
Triglyceride $(\mathrm{mg} / \mathrm{dl})$ & 77 & 93 & 92 & 87 & 108 & 108 & 94 & 99 & 6.3 \\
Total lipid $(\mathrm{mg} / \mathrm{dl})$ & 454 & 480 & 545 & 686 & 575 & 419 & 582 & 702 & 5.6 \\
Total protein $(\mathrm{g} / \mathrm{dl})$ & 6.5 & 6.5 & 6.8 & 6.9 & 6.5 & 6.7 & 6.7 & 6.9 & 0.5 \\
Albumin $(\mathrm{g} / \mathrm{dl})$ & 3.1 & 2.9 & 3.0 & 3.1 & 3.2 & 3.1 & 3.1 & 2.8 & 0.2 \\
AST $(\mathrm{RFU} / \mathrm{ml})$ & 62.3 & 50.0 & 72.7 & 56.3 & 77.7 & 53.3 & 51.7 & 59.3 & 6.9 \\
ALT $(\mathrm{RFU} / \mathrm{ml})$ & 32.3 & 22.3 & 21.7 & 35.0 & 23.7 & 28.3 & 29.0 & 31.7 & 5.6 \\
\hline
\end{tabular}

Note. Data indicate mean, $\mathrm{n}=3$ /group. Control $(\mathrm{C})$, basil $(\mathrm{B})$, thyme $(\mathrm{T})$, basil + thyme $(\mathrm{BT})$, zymogen $(\mathrm{Z})$, kemzyme $(\mathrm{K})$, basil + thyme + kemzyme (BTK), basil + thyme + zymogen (BTZ), pooled standard error (SE pooled).

\subsection{Effect of Basil, Thyme, (Basil + Thyme), Zymogen, Kemzyme, (Basil + Tyme + Kemzyme) and (Basil + Thyme + Zymogen) on Serum Superoxide Dismutase (SOD) U/ml, Total Antioxidant Capacity (TAC) mM/L and Lipid Peroxidation Malondialdehyde (MDA) nmol/ml}

The illustrated results of serum antioxidant activity in Table 4 of turkey toms at the end of experimental period (10 weeks), recorded that there was a significant decrease in activity of lipid peroxide (Malondialdehyde) in groups of toms supplemented with (B) while those toms supplemented with (T) or (BT) or (BTK) or (BTZ) revealed significant activities of lipid peroxidase (MDA) Moreover the same table shows the (MDA) activity in serum of toms supplemented with $(\mathrm{K})$ or $(\mathrm{B})$ or $(\mathrm{Z})$ had no change versus control group. The present results are proud with those obtained by Hamada et al. (2015) which reported that broilers supplemented with basil showed a significant increase of SOD and TAC. While the result of MDA in all groups contradict the former recorded data by the same author. Moreover, Dusgupta et al. (2004) reported that O. basilica increase activity antioxidant enzyme responses by significantly increasing activities of the hepatic glutathione reductase, superoxide dismutase and catalase activity in liver. Also, Hussain et al. (2008), and Meera et al. (2009) added that basil extract showed significant anti-lipid peroxidation effect in vitro, in addition to exhibiting significant activity in scavenging superoxide radical and nitric oxide radicals indicating potent antioxidant effect.

MDA is one of the most frequently used biomarkers providing an indicator of the overall lipid peroxidation and may be a potential biomarker for oxidative stress (Killie et al., 2003). The decrease of (MDA) activities may be due to antioxidant activities of basil (Seung-Jool et al., 2005; Hussein et al., 2008; Zhang et al., 2009; Meera et al., 2009) on the other hand values of superoxide dismutase (SOD) illustrate no differences in all groups. Meanwhile, the serum total antioxidant capacity (TAC) recorded significant higher values in all experimental groups compared to that level of control. At the same time, the present values of MDA for groups supplemented with (T) is opposite to the finding of Bolukbasi et al. (2006) and Schiavone et al. (2007) who considered thyme leaves and their contents of biphenylic as well as flavinoid compounds have been found to exhibit antioxidant capacity. As well as Rahim et al. (2011) assured that thyme and oregano contain large amount of monotrepens thymol, carvacrol and flavinoids are exerting antioxidant properties. Concerning the increase of SOD in group supplemented with thyme (Shwartiz et al., 1996; Yanishlieva et al., 1999) recorded that, Phenolic components like carvacrol and thymol were found to be responsible for the stabilization of thyme oil due to their antioxidant activities Tymol and carvacrol are reported to inhibit lipid peroxidation. Moreover, the phenolic trepens improved stability of poultry production by decreasing lipid peroxidation. (Schiavone et al., 2007) suggested that high antioxidant activity of the thymol is due to the presence of phenolic hydroxy $(\mathrm{OH})$ group that act as hydrogen donors to the proxy radicals which are produced during the first step of lipid oxidation which in turn retard the hydroxyl peroxide formation.

Moreover, Hashimpour (2012) found that chicken supplemented with thymol caused an increase in SOD activity while MDA was reduced in the liver and serum by these inclusions thus the active substance of these phytogenic products may improve the antioxidant status due to antioxidant properties of thymol and carvacrol by elevating the activity of antioxidant enzymes.

Concerning the total antioxidant capacity (TAC) measures the overall antioxidant capacity (Sharma \& Kaur, 2015) Assured the antioxidant properties of all used feed additives ((T), (B), (K), (Z), (BTK) and (BTZ)) by the obtained higher values of (TAC) of all groups. Sometimes the present data of superoxide dismutase (SOD) 
which contribute to the first line of antioxidant pathway as it plays a role in the defense of cell against the toxic effects of oxygen radicals (Chakraborty et al., 2009).

Table 4. Effect of basil, thyme, (basil + thyme), zymogen, kemzyme, (basil + thyme + kemzyme) and (basil + thyme + zymogen) on serum superoxide dismutase (SOD) $(\mathrm{U} / \mathrm{ml})$, total antioxidant capacity (TAC) (mM/L) and lipid peroxidation (malonaldehyde) MDA (nmol/ml)

\begin{tabular}{llllllllll}
\hline \multirow{2}{*}{ Anti-Oxidants } & \multicolumn{10}{c}{ Group } \\
\cline { 2 - 9 } & C & B & T & BT & Z & K & BTK & BTZ & SE pooled \\
\hline MDA (nmol/ml) & 34 & 30 & 39 & 47 & 32 & 37 & 39 & 42 & 3.0 \\
SOD (U/ml) & 200.8 & 202.1 & 202.1 & 203.4 & 199.9 & 201.7 & 200.9 & 201.5 & 2.1 \\
TAC (mM/L) & 0.6 & 1.6 & 0.8 & 2.1 & 1.7 & 0.9 & 1.5 & 1.9 & 0.1
\end{tabular}

Note. Data indicate mean, $\mathrm{n}=3$ /group. Control $(\mathrm{C})$, basil $(\mathrm{B})$, thyme $(\mathrm{T})$, basil + thyme $(\mathrm{BT})$, zymogen (Z) kemzyme $(\mathrm{K})$, basil + thyme + kemzyme (BTK), basil + thyme + zymogen (BTZ), pooled standard error (SE pooled).

\subsection{Effect of Basil, Thyme, (Basil + Thyme), Zymogen, Kemzyme, (Basil + Thyme + Kemzyme) and (Basil + Thyme + Zymogen) on Serum Thyroid Hormones $\left(T_{3} \& T_{4}\right)$}

Turkeys supplemented with B and BTZ recorded a significant increase in serum $\mathrm{T}_{4}$ level compared to $\mathrm{C}$ while group supplemented with Z, BTK and BTZ showed significantly higher $\mathrm{T}_{3}$ level compared to control.

Iqbal et al. (1990) and Yahav et al. (1998) pointed the relation between ambient temperature, feed intake, growth rate and plasma $\mathrm{T}_{3}$ levels may be associated with changes in structural and function of intestinal tract. Supplementation of turkey ration in the current study with (B), (BT) and enzymes exhibited significant increase in the concentration of serum $T_{3}$ this increase in $T_{3}$ level after treatment with herbs and enzymes may be due to enhancement of the digestion of food and absorption of nutrients, similar results obtained by Adams (2001), Ahmed et al. (2013) ,Collin et al. (2003), Hajati et al. (2009), and Saleh et al. (2006) who revealed that blood level of $\mathrm{T}_{3}$ was elevated in broiler supplemented with enzymes while $\mathrm{T}_{4}$ level was not significantly affected. Mousa (2008) found that no difference was observed in serum $\mathrm{TSH}$ and serum $\mathrm{T}_{4}$ in broilers supplemented with polyzyme. This might be attributed to the direct or indirect stimulatory effect of the de-iodinaze activity in liver and kidney tissue promoting the transformation of $\mathrm{T}_{4}$ to $\mathrm{T}_{3}$ as described. A positive linear correlation has been found in chicken and turkeys between plasma $T_{3}$ level and feed intake and growth rate (Yahav et al., 1998).

Table 5. Effect of basil, thyme, basil + thyme, zymogen, kemzyme, basil + thyme + zymogen and basil + thyme + kemzyme on serum thyroxine level $\left(\mathrm{T}_{4}\right)(\mathrm{ug} / \mathrm{dl})$ and tri-iodothyronine level $\left(\mathrm{T}_{3}\right)(\mathrm{nmol} / \mathrm{L})$

\begin{tabular}{llllllllll}
\hline \multirow{2}{*}{ Hormone } & \multicolumn{10}{c}{ Group } \\
\cline { 2 - 9 } & $\mathrm{C}$ & $\mathrm{B}$ & $\mathrm{T}$ & $\mathrm{BT}$ & $\mathrm{Z}$ & $\mathrm{K}$ & $\mathrm{BTK}$ & $\mathrm{BTZ}$ & SE pooled \\
\hline $\mathrm{T}_{4}$ & 1.4 & 2.1 & 1.4 & 1.6 & 1.2 & 1.5 & 1.6 & 2.0 & 0.8 \\
$\mathrm{~T}_{3}$ & 4.7 & 8.6 & 4.2 & 8.0 & 7.2 & 9.4 & 6.9 & 7.6 & 0.5 \\
\hline
\end{tabular}

Note. Data indicate mean, $\mathrm{n}=3$ /group. Control (C), basil (B), thyme $(\mathrm{T})$, basil + thyme (BT), zymogen $(\mathrm{Z})$ kemzyme $(\mathrm{K})$, basil + thyme + kemzyme $(\mathrm{BTK})$, basil + thyme + zymogen $(\mathrm{BTZ})$, pooled standard error $(\mathrm{SE}$ pooled).

\subsection{Effect of Basil, Thyme, (Basil + Thyme), Zymogen, Kemzyme, (Basil + Thyme + Kemzyme) and (Basil + Thyme + Zymogen) on Intestinal Villous Length, Crypt Depth and Number of Goblet Cells}

It is well known that the intestinal lumen is protected with developed healthy integrity of intestinal wall. Continuous layer of epithelial cells which is formed as a proliferation of crypt cells, that differentiate into mature cells (absorptive, goblet, and enteroendocrine cells). Also, part of the epithelial differentiation the so called villous structure (the main absorptive area). The villous height and crypt depth are studied by many authors (Ferrer et al., 1995; Uni et al., 1995, 1996, 1998). The functional integrity of the intestinal mucosal epithelial cells depends on coordinated regulation of the mucus layer which is main secretory product of goblet cells which serve as the front line of innate host defense mechanism (Kim \& Samuel, 2010).

The results obtained from the present study (Table 6, Figures 1 and 2) revealed that, dietary supplementation of (T), (Z) or (BTK) groups induced higher values of villous height in comparison of those supplemented with (B), 
(BT), (K), (BTZ) or (C) groups. At the same time, all groups supplemented with either herbs or enzymes recorded a higher significant ratio of villous height to crypt depth $(\mathrm{V} / \mathrm{C})$ in comparisons to those of control group. Similar results were obtained by Loodi et al. (2004) and Mathalothi et al. (2002) who concluded that the exogenous enzymes improved nutrient digestibility leading to increasing the villous surface and concentration of conjugated bile salts. Moreover, Ahmed et al. (2013), Bala murugan et al. (2011), Neto et al. (2012), and Zikic et al. (2008) stated that enzymes are able to increase the villi height and width and reduce height and width of crypts. These changes were represented by elongation of villi and a higher villi/crypt depth ratio which indicate lower rate of enterocytes migration from crypts to the villous.

Moreover, the increase in villous height of turkey toms supplemented with thyme $(\mathrm{T})$ in their diet in the present study showed that intestinal mucosal architecture can reveal information on intestinal function, increasing the villous height suggests an increased surface area for greater absorption of available nutrients as recommended by (Awad et al., 2009). Also, the present results revealed that (V/C) was higher in thyme (T), thyme plus basil (BT) treated groups versus control. This increase is related to increase digestion\& absorption (Montague et al., 2003; Plusk et al., 1996).

Contradictory results obtained by Guo et al. (2004), and Garcia et al. (2007) who found no differences in intestinal morphology among groups receiving either medicinal plants or a blend of plant extract. Moreover, Peric et al. (2010), and Shams Sharph (2012) pointed that, phytogenic blend did not affect villous height, but caused the highest crypt depth and lower villous height/crypt depth (V/C). Consent the previous finding of Xu et al. (2003) that antimicrobial agents such as essential oils or their active components are known to reduce the intestinal microbial load which in turn reduces the presence of toxins that associated with the changes in intestinal histomorphology such as villous height and crypt depth. Moreover, Ocak et al. (2008) suggests that thyme leaves as growth promotors in broilers feed had no effect on relative weights of whole gut but, with other mechanism. Thus, indicate that the improved production results obtained in broilers fed phytogenic additives are not directly connected the improved gut morphology,

The obtained results revealed that the highest number of goblet cells was recorded in basil and basil plus thyme supplementation groups. Similar results were obtained by Jamaroz et al. (2006) who observed quantitative increases in the number of goblet cells and mucin secretion at the surface of the villi when feeding broilers, a mixture of plant extract contain carvacrol.

Although the density of goblet cells may result in an increase in mucin secretion, the number of goblet cells cannot be used to quantify this mucin secretion. The mucus layer plays key roles in the establishment of the commensal intestinal microbiota and the protection from colonization and invasion by the pathogenic microbiota (Kim \& Samuel, 2010).

Table 6. Effect of basil, thyme, (basil + thyme), zymogen, kemzyme, (basil + thyme + kemzyme) and (basil + thyme + zymogen) on intestinal villus length $(\mu \mathrm{m})$, villus width $(\mu \mathrm{m})$, crypt depth $(\mu \mathrm{m})$, villus length to crypt depth ratio and number of goblet cells/villus in turkey duodenum

\begin{tabular}{|c|c|c|c|c|c|c|c|c|c|}
\hline \multirow{2}{*}{ Parameter } & \multicolumn{9}{|c|}{ Group } \\
\hline & $\mathrm{C}$ & B & $\mathrm{T}$ & BT & Z & $\mathrm{K}$ & BTK & BTZ & SE Pooled \\
\hline VL (mean) & 978 & 643 & 1187 & 682 & 1317 & 1028 & 605 & 1290 & 67.4 \\
\hline Min & 876 & 611 & 1125 & 603 & 1300 & 960 & 519 & 1225 & \\
\hline Max & 1055 & 688 & 1322 & 822 & 1350 & 1106 & 672 & 1340 & \\
\hline $\mathrm{CD}$ (mean) & 388 & 85 & 208 & 96 & 277 & 200 & 72 & 107 & 48.6 \\
\hline Min & 322 & 79 & 106 & 80 & 147 & 157 & 54 & 92 & \\
\hline Max & 489 & 96 & 284 & 111 & 342 & 273 & 96 & 127 & \\
\hline V/C Ratio & 3.00 & 8.00 & 6.00 & 7.00 & 5.00 & 5.00 & 8.60 & 12.00 & 1.0 \\
\hline NGC (mean) & 74 & 121 & 79 & 106 & 27 & 69 & 179 & 91 & 8.6 \\
\hline Min & 68 & 112 & 72 & 98 & 23 & 65 & 86 & 162 & \\
\hline Max & 82 & 130 & 85 & 117 & 32 & 75 & 95 & 192 & \\
\hline VW (mean) & 12.4 & 11.0 & 10.3 & 9.3 & 14.6 & 10.1 & 10.6 & 11.7 & 1.2 \\
\hline Min & 9.2 & 9.2 & 9.6 & 8.1 & 12.8 & 9.1 & 9.6 & 9.8 & \\
\hline Max & 13.9 & 13.8 & 11.5 & 10.3 & 16.5 & 11.3 & 11.5 & 13.5 & \\
\hline
\end{tabular}

Note. Data indicate mean, $\mathrm{n}=4$ /group. Control $(\mathrm{C})$, basil $(\mathrm{B})$, thyme $(\mathrm{T})$, basil + thyme $(\mathrm{BT})$, zymogen $(\mathrm{Z})$ kemzyme (K), basil + thyme + kemzyme (BTK), basil + thyme + zymogen (BTZ), VL (villus length), VW (villus width), CD (crypts depth), NGC (number of goblet cells). 


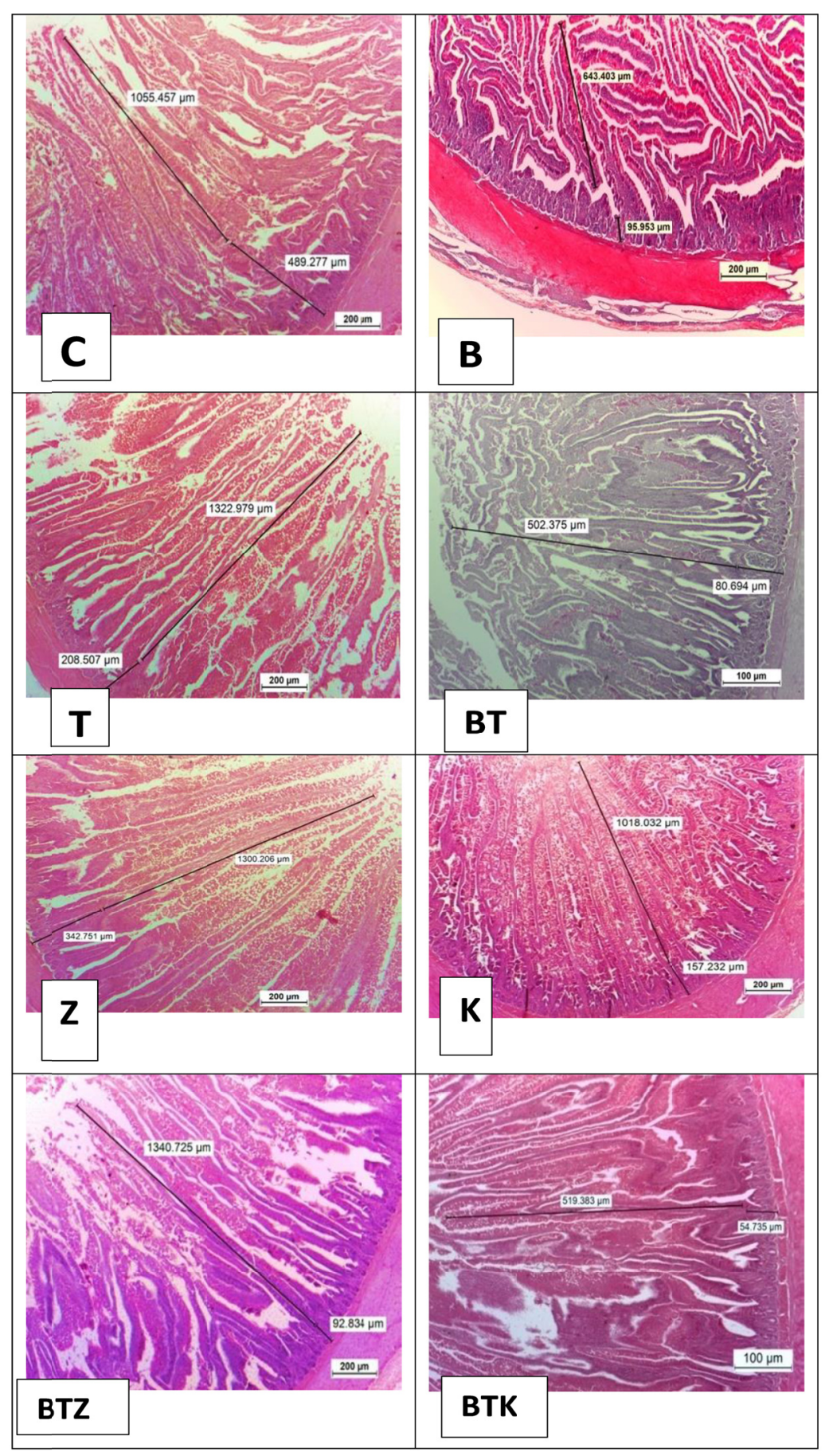

Figure 1. Photomicrographs of the small intestine (duodenum) from male turkey chicken showing the villous heights, crypt depths (H\&E X40)

Note. Control (C), basil (B), thyme (T), basil + thyme (BT), zymogen (Z), kemzyme (K), basil + thyme + kemzyme (BTK), basil + thyme + zymogen (BTZ). 


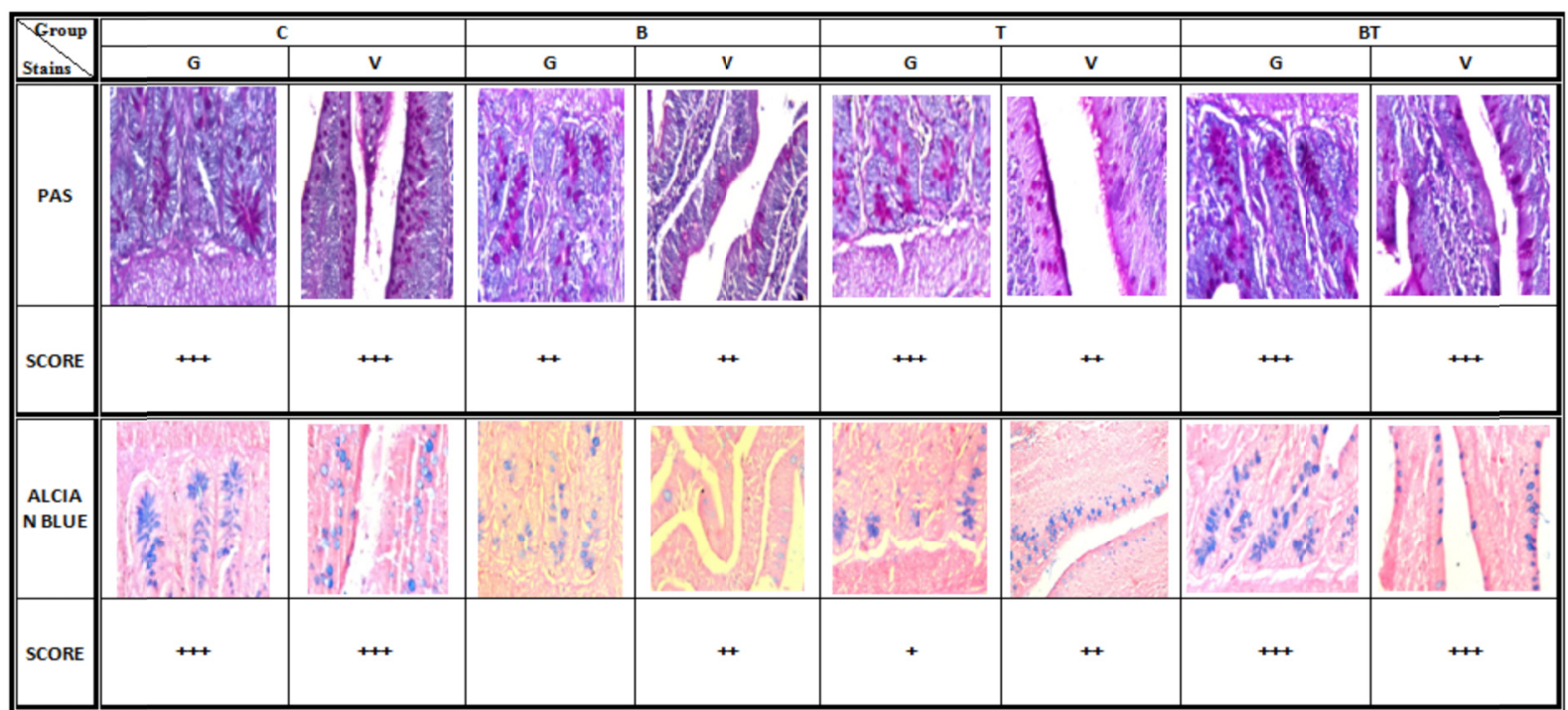

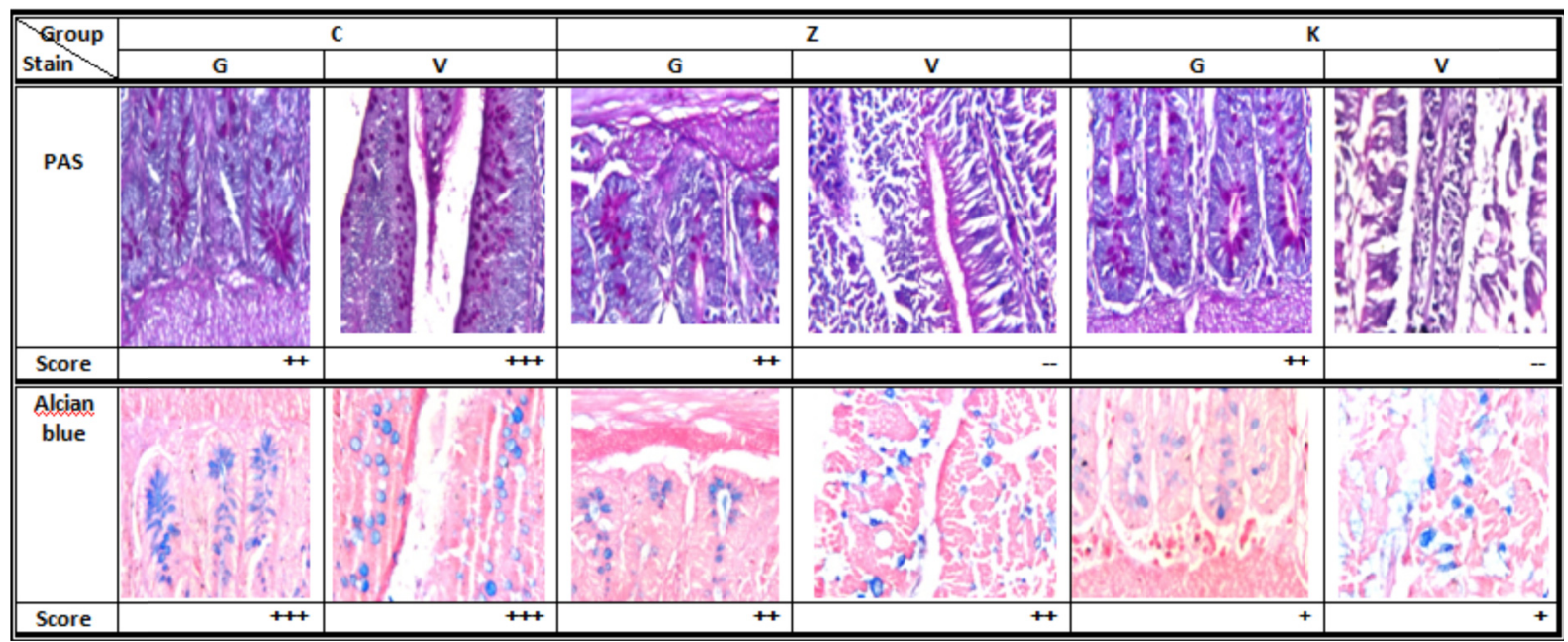

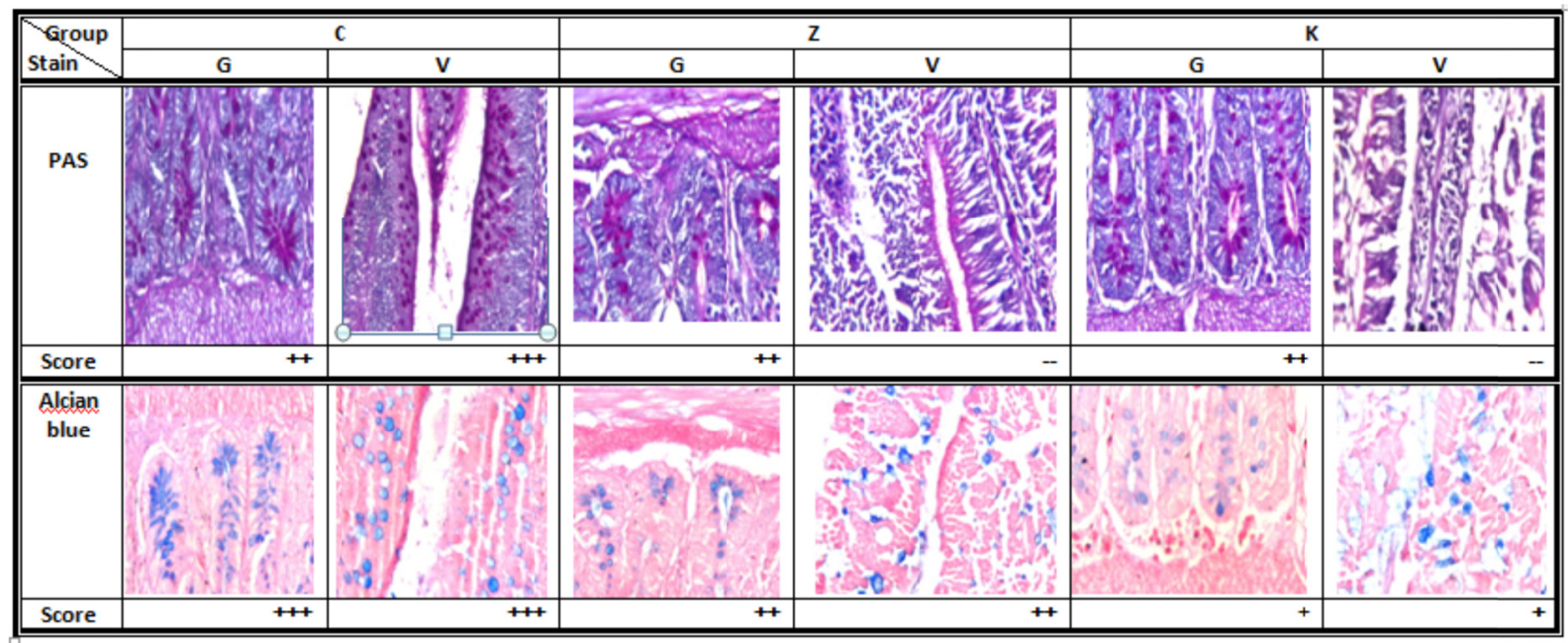

Figure 2. Showing the histochemical alteration in mucin of the intestinal mucosa of different experimental groups (H\&E X40)

Note. $\mathrm{G}=$ gland, $\mathrm{V}=$ Villi mucosa.+++ severe,++ moderate, + mild, -- nil. 
3.6 Effect of Basil, Thyme, (Basil + Thyme), Zymogen, Kemzyme, (Basil + Thyme + Kemzyme) and (Basil + Thyme + Zymogen) on Intestinal DNA, RNA Concentration and Protein Synthesis

The determination of DNA, RNA and protein concentration in of intestinal tissue, together with morphological measurements, has provided novel knowledge about intestinal development and integrity such as, DNA/RNA ratio, DNA/Protein ratio (Uni \& Saklan, 1999). The DNA concentration in a tissue reflects its rate of mitosis in a cell population, with the protein to DNA ratio indicating the cell size (Jin et al., 1998).

The present data recorded (Table 7) a significant increase in the total DNA of duodenal tissue of the groups supplemented with (B), (T), (Z), (BTK) or (BTZ). Moreover, the revealed results of DNA/protein of the duodenal tissues indicate higher ratio. These results increase DNA concentration in the duodenal tissue and reflect its mitoses in cell population which consent of Jin et al. (1998). The same table revealed a decrease of RNA concentration of most experimental groups (T), (K) and (BTK). The former obtained results go hand by hand with the previous suggestions of Jin et al. (1998), Uni et al. (1998), and Iji (1999) indicated that the concentration of DNA, RNA and their ratio to protein content, undergo variation and these variation not always consistent and differ from species or breed to others.

Taking the concepts of the all former authors in consideration of the development and cell size the present results recorded that supplementation of $(\mathrm{T})$ and $(\mathrm{BTK})$ increase the DNA/RNA, DNA/Protein and RNA/Protein. Meanwhile, RNA/Protein was increased by supplementation of most of the used feed additives (T), (B), (BT), (Z) and (BTZ). Also, the ratio of Protein/DNA increased only in group supplemented with (K). The variable results may be due to individual variation or the more short duration and late time (age of toms) of experimental application.

Herbs and botanicals contain many different antioxidants with a high potential for the protection of nutrient against oxidation and digestive tract in metabolism as well as in the products Several phytochemicals like essential oils or dietary fiber can contribute a balanced microflora (Eubiosis) and optimal precondition for an effective production against pathogenic microorganisms and intact immune system (Casper, 2003).

Table 7. Effect of basil, thyme, (basil + thyme), zymogen, kemzyme, (basil + thyme + kemzyme) and (basil + thyme + zymogen) on intestinal DNA, RNA concentration and protein synthesis

\begin{tabular}{lllllllll}
\hline \multirow{2}{*}{ Parameter } & \multicolumn{1}{c}{ Group } \\
\cline { 2 - 10 } & $\mathrm{C}$ & $\mathrm{B}$ & $\mathrm{T}$ & $\mathrm{BT}$ & $\mathrm{Z}$ & $\mathrm{K}$ & $\mathrm{BTK}$ & $\mathrm{BTZ}$ \\
\hline DNA $(\mathrm{ng} / \mu \mathrm{l})$ & 124 & 254 & 532 & 337 & 674 & 158 & 1440 & 685 \\
RNA $(\mathrm{ng} / \mu \mathrm{l})$ & 1530 & 728 & 415 & 1045 & 1105 & 410 & 181 & 835 \\
Protein $(\mathrm{ng} / \mu \mathrm{l})$ & 0.92 & 0.96 & 0.98 & 1.49 & 0.97 & 1.49 & 1.51 & 0.93 \\
DNA/RNA & 0.08 & 0.35 & 1.28 & 0.32 & 0.61 & 0.39 & 7.96 & 0.82 \\
DNA/Protein & 135.4 & 264.3 & 541.8 & 226.2 & 695.6 & 105.8 & 955. & 738.1 \\
RNA/Protein & 1663 & 758.3 & 423.5 & 701.3 & 1139 & 275.2 & 119.9 & 897.9 \\
Protein/DNA & 0.007 & 0.004 & 0.002 & 0.004 & 0.001 & 0.009 & 0.001 & 0.001 \\
\hline
\end{tabular}

Note. Data indicate mean, $\mathrm{n}=3$ /group. Control $(\mathrm{C})$, basil $(\mathrm{B})$, thyme $(\mathrm{T})$, basil + thyme (BT), zymogen (Z), kemzyme (K), basil + thyme + kemzyme (BTK), basil + thyme + zymogen (BTZ), pooled standard error (SE pooled).

\section{Conclusion}

Supplementation of turkey rations with herbs (basil \& thyme) and multienzymes (zymogen \& kemzyme) either alone or in combination produce a significant improvement in turkeys' performance:

(1) They may regulate feed intake.

(2) Increase intestinal surface area for more absorption and utilization of feed.

(3) Contain different antioxidants activity.

All additives used in the experiment were safe and did not alter liver function and they improved all measured growth and metabolic parameters.

\section{References}

Abaza, I. M., \& Omara, M. E. (2011). Effect of dietary corn cobs and enzymes supplementation on growing rabbit's performance. J. Product. \& Dev., 16(3), 507-527. 
Abbas, R. J. (2010). Effects of using Fenugreek, Parsley and Sweet Basil seeds as feed additives on the performance of broiler chickens. International Journal of Poultry Science, 9(3), 278-282. https://doi.org/ 10.3923/ijps.2010.278.282

Abdel-Azeem, F. (2006). Effect of using fenugreek and fennel seeds as natural feed additives on performance of broiler chicks. Egypt. J. Nurt. Feeds, 9, 277-297.

Abdl-RAhman, M. A., Sawiriess, F. A. R., \& Sohair, Y. S. (2010). Effect of kemzyme bontonite co-supplementation on ceacal fermentation and metabolic pettern in rabbit. Journal of Agriculture of Science, 2(3), 183. https://doi.org/10.5539/jas.v2n3p183

Adams, C. A. (2001). Interaction of feed enzymes and antibiotic growth promotors on broiler performance. In J. Brufau (Ed.), Feed manufacturing in the Mediteranean region. Improving safety: From feed to food (pp. 71-74). Zaragoza: CIHEAM-IAMZ.

Ahmed, H. H., El-Toukhy, N. S., Attia, K. A., \& El-Samannoudy, S. I. (2013). Effect of multienzymes and absorption enhancers on productive performance, gut morphology some blood biochemical and hormonal parmeters in broiler chicks. J. Agri. Sci., 5(12), 162-179.

Ahmed, M. R., Osman, H. M., Abdel, W., \& Mona, S. R. (2011). Performance and carcass characteristics of broiler chicks fed diet supplemented with some medicinal and aromatic plant. Anim. Prod. Research Institute.

Aji, S. B., Ignatius, K., Adatu, A., Ado Y., Nuhu, J. B., \& Abdulkarim, A. (2011). Effects of Feeding Onion (Allium cepa) and Garlic (Allium sativum) on Some Performance Characteristics of Broiler Chickens. Research Journal of Poultry Sciences, 4(2), 22-27. https://doi.org/10.3923/rjpscience.2011.22.27

Al-Kassie, A. M. (2009). Influence of two plant extracts derived from thyme and cinnamon on broiler performance. Pakistan Veterinary Journal, 29(4), 169-173.

Alloui, N., Ben Aksa, S., Alloui, M. N., \& Ibrir, F. (2012). Utilization of Fenugreek (Trigonella foenum Graecum) as Growth Promoter for Broiler Chickens. J. World's Poult. Res. 2(2), 25-27.

Awad, W. A., Ghareeb, K., Abdel-Raheem, S., \& Böhm, J. (2009). Effects of dietary inclusion of probiotic and synbiotic on growth performance, organ weights, and intestinal histomorphology of broiler chickens. Poult. Sci., 88, 49-56. https://doi.org/10.3382/ps.2008-00244

Bala Murugan, R., Chandrasekaran, D., \& Kirubakaran, A. (2011). Effect of Multi enzyme supplementation on gut morphology and histo morphology in broilers. Ind. J. of Sci and Technology, 4(1), 15-18.

Bolukbasi, Ş. C., Erhan, M. K., \& Özkan, A. (2006). Effect of dietary thyme oil and vitamin E on growth, lipid oxidation, meat fatty acid composition and serum lipoproteins of broilers. S. Afr. J. Anim. Sci., 36, 189-196.

Brancroft, J., Stevens, A., \& Turner, D. (1996). Theory and practice of histological techniques (4th ed.). Churchil Living Stone, New York, London, San Fransisco, Tokyo.

Bret, L. (2003). Two independent Samples. Department of Statistics, University of Wisconsin, Madison, USA.

Breuer, J. (1996). Drug effects in clinical chemistry methods. Eur J Clin Chem Clin Biochem, 34, 385-386.

Bucolo, G., \& David, H. (1973). Quantitative determination of serum triglycerides by the use of the enzymes. Clin Chem, 19, 457.

Caspar, W. (2003). Herbs and botanicals as feed additives in monogastric animals. Asian-Aust. J. Anim. Sci., 16(2), 282-289. https://doi.org/10.5713/ajas.2003.282

Chakaborty, P., Kumar, S., Dutta, D., \& Gupta, V. (2009). Role of antioxidants in common health disease. Res. J. Pharm. and Tech., 2, 238-244.

Choct, M., \& Annison, G. (1992). The inhibition of nutrient digestion by wheat pentosans. Br. J. Nutr., 67, 123-132. https://doi.org/10.1079/BJN19920014

Collin, A., Malheiros, R. D., Moraes, V. M. B., Veerle, P. V. A., Darras, M., Taouis, M., ... Buyse, J. (2003). Effects of dietary macronutrient content on energy metabolism and uncoupling protein mRNA expression in broiler chickens. Br. J. Nutr., 90, 261-269. https://doi.org/10.1079/BJN2003910

Darshana, B. B., \& Thyagarajan, D. (2014). Effect of Four Herbal Seeds on Blood Parameters in Turkey Poults. International Journal of Science and Research, 3(8), 235-240. 
Demir, E., Sarica, S., Ozcan, M. A., \& Suicmez, M. (2005). The use of natural feed additives as alternative to an antibiotic growth promoter in broiler diets. Arch. Geflugelkd., 69, 110-116,

Douglas, M. W., Parsons, C. M., \& Bedford, M. R. (2000). Effects of various soybean meal sources and Avizyme ${ }^{\circledR}$ on chick growth performance and ileal digestible energy. J. Appl. Poult. Res., 9, 74-80. https://doi.org/10.1093/japr/9.1.74

Dusgupta, T., Rao, A. R., \& Yadav, P. K. (2004). Chemomodulatory efficacy of basil leaf (Ocimum basillicum) on drug metabolizing and antioxidant enzymes and on carcinogen induced skin and forest papillomagenesis. Phytomedicine, 11, 139-151. https://doi.org/10.1078/0944-7113-00289

Ellfeson, R. D., \& Carawy, W. T. (1976). In N. W. Tietz (Ed.), Fundamentals of clinical chemistry (p. 506).

Falcao-e-Cunha, L., Castro-Solla, L., Maertens, L., Marounek, L., Pinheiro, V., Freire, J., \& Mourao, J. L. (2007). Alternatives to antibiotic growth promoters in rabbit feeding: A review. World Rabbit Sci., 15, 127-140.

Feizi, A., Bijanzad, P., \& Kaboli, K. (2013). Effects of thyme volatile oils on performance of broiler chickens. Euro. J. Exp. Bio., 3, 250-254.

Ferrer, R., Ptanas, J. M., \& Morelo, M. (1995). Cellapical surface area in enterocytes from chicken small and large intestine during development. Poult. Sci., 74, 1995-2002. https://doi.org/10.3382/ps.0741995

Fischer, M., \& Suttle, C. (2011). A virophage at the origin of large DNA transposons. Science, 332, $231-4$. https://doi.org/10.1126/science. 1199412

Galinish, K., \& Halle, I. (2001). Effect of essential oil and herbs in animal nutrition. Proc. $8^{\text {th }}$ SWM in Vit. and Additive Nutrition of Man and Animal (Pt.32-Abstr., pp. 26-27).

Garcia, V., Catala-Gregori, V., Hernandez, F., Megias, M. D., \& Madrid, J. (2007). Effect of formic acid \& plant extracts on growth, nutrient digestability, intestine mucosa morphology and meat yield of broiler. J. Appl. Poult. Res., 16, 535-562. https://doi.org/10.3382/japr.2006-00116

Grant, G. H., Silverman, L. M., \& Christenson, R. H. (1987). Aminoacids and proteins. In N. W. Tietz (Ed.), Fundamentals of Clinical Chemistry (3rd ed., pp. 291-345). Philadelphia: WB Saunders.

Guo, F. C., Kwakkel, R. P., Soede, J., \& Williams, B. A. (2004). Effect of a Chinese herb medicine formulation as an alternative for antibiotics on performance of broiler. Br. Poult. Sci., 45, 793-797. https://doi.org/ $10.1080 / 00071660400012741$

Hajati, H. (2010). Effect of enzyme supplementation on performance, carcass composition and some blood parameters of broiler chicken. American Journal of Animal and Veterinary Sciences, 5(3), 221-227. https://doi.org/10.3844/ajavsp.2010.221.227

Houshmand, M., Azhar, K., Zulkifi, I., Bejo, M. H., Meimandipour, A., \& Kamyab, A. (2011). Effect of non-antibiotic feed additives on performance tibila dyschondroplasia incidence and tibia characteristics of broilers fed low calcium diets. Animal Physiology and Animal Nutrition, 95, 351-358. https://doi.org/ 10.1111/j.1439-0396.2010.01061.x

Hussain, A. I., Anwar, F., Sherazi, S. T. H., \& Przybylski, R. (2008). Chemical composition, antioxidant and antimicrobial activities of basil (Ocimum basilicum) essential oils depends on seasonal variations. J. Food Chem., 108, 986-995. https://doi.org/10.1016/j.foodchem.2007.12.010

Iji, P. A. (1999). The impact of cereal non-starch polysaccharide on intestinal development and function in broiler chickens. World Poult. Sci. J., 55, 375-387. https://doi.org/10.1079/WPS19990026

Iqbal, A., Decuyper, E., Abd El-Azim, A., \& Kuhn, E. R. (1990). Pre- and Post- Hatch high temperature exposure affects the thyroid hormones and corticosterone response to acute heat stress in growing chicken (Gallus domesticus). J. Therm. Biol., 15(2), 149-153. https://doi.org/10.1016/0306-4565(90)90032-D

Isa, J. A. A. (2011). Performance and lipid profile of broilers fed two medicinal plants. Retrieved from https://scholar.najah.edu/node/7657

Jamaroz, D., Wertelecki, T., Houszka, M., \& Kamel, C. (2006). Influence of diet type on the inclusion of plant origin active substances on morphological and histochemical characteristics of the stomach and jeujenum walls of chicken. J. Anim. Physiol. Anim. Nutri., 90, 255-268. https://doi.org/10.1111/j.1439-0396.2005. 00603.x 
Jin, L. Z., Ho, Y. W., Abdullah, N., \& Jalaludin, S. (1998). Growth performance intestinal microbal population and serum cholesterol of broilers fed diet containing lactobacillus cultures. Poult. Sci., 77, 1259-1265. https://doi.org/10.1093/ps/77.9.1259

Kaplan, A., \& Szalbo, J. (1983). In A. Kaaplan \& J. Szabo (Eds.), Clinical chemistry: Interpretation and techniques (2nd ed., p. 157).

Khan, R. U., Durrani, I. R., \& Chand, N. (2010). Influence of feed supplementation with cannabis saliva on quality of broiler carcass. Pakistan Veterinary Journal, 309, 34-38.

Khan, R. U., Naz, S., Nikousfat, Z., Tufarelli, V., Janvdani, M., Qureshi, M. S., \& Laudadio, V. (2012). Potential application of ginger (Zingiber officinale) in poultry diet. World Poultry Science Journal, 3, $245-252$. https://doi.org/10.1017/S004393391200030X

Khan, R. U., Naz, S., Tufarelli, V., Selvaggi, M., \& Laudadio, V. (2011). The use of turmeric (Curcuma longa) in poultry feed. World Poultry Science Journal, 68, 97-103. https://doi.org/10.1017/S0043933912000104

Khan, R. U., Nikousefat, Z., Tufarelli, V., Naz, S., Javdani, M., \& Laudadio, V. (2012). Garlic (Allium sativum) supplementation in poultry diets: Effect on production and physiology. World Poultry Sci. J., 68, 417-424. https://doi.org/10.1017/S0043933912000530

Killie, E., Yazar, S., Sarayman, R., \& Hozbilge, H. (2003). Serum Malondialdehyde level in patients infected with Ascaris lumbicodes.World J. Gastroentro., 9, 2332-2334. https://doi.org/10.3748/wjg.v9.i10.2332

Kim, Y. S., \& Samuel, B. H. (2010). Intestinal goblet cells and mucus in health and disease. Curr. Gastroenterol Rep., 12(5), 319-330. https://doi.org/10.1007/s11894-010-0131-2

Koracevic, D., Koracevic, G., Djordjevic, V., Andrejevic, S., \& Cosic, V. (2001). Method for the measurement of antioxidant activity in human fluids. J. Clin. Pathol., 54, 356-361. https://doi.org/10.1136/jcp.54.5.356

Langhout, P. (2000). New additives for broiler chickens. World Poultry, 16, 22-27.

Lee, K. W., Everts, H., Kappery, H., Frehnen, M., Losa, R., \& Beyman, A. C. (2003). Effect of dietary essential oil components on growth performance, digestive enzyme and lipid metabolism in female broiler chickens. Br. Poult. Sci., 44(3), 450-457. https://doi.org/10.1080/0007166031000085508

Lewis, M. R., Rose, S. P., Machenzie, A. M., \& Tucker, L. A. (2003). Effect of dietary inclusion of plant extracts on the growth performance of male broiler chickens. Br. Poult. Sci., 44, s43-s44. https://doi.org/10.1080/ 00071660301940

Loodi, M. M., Moraes, V. B. M., Nakaghi, L. S. O., Tuca, F. M., Hannas, M. I., \& Ariki, J. (2004). Mannan oligosaccharide, organic acids on performance and intestinal morphometric characteristic of broiler chicken (p. 45). Abstract of Alltechs 20th Annual Symposium, Nicholas ville, Kentuchy, USA.

Mamoun, T., Mukhtar, A., \& Tabidi, M. H. (2014). Effect of fenugreek seed powder on the performance, carcass characteristics and some blood serum attributes. Adv. Res. Agri. Vet. Sci., 1, 6-11.

Mansoub, N. H. (2011a). Comparison of effects of using thyme and probiotic on performance and serum composition of broilers chicken. Advances in Environmental Biology, 5, 2012-2015.

Mansoub, N. H. (2011b). Assessment on effect on thyme on egg quality and blood parameters of laying hens. Annals of Biological Research, 2, 417-422.

Margovi, D. P., Beauchemin, K. A., Nsereko, V. L., Rode, L. M., McAllister, T. A., Iwaasa, A. D., ... Yang ,W. Z. (2001). Resistance of feed enzymes to proteolytic inactivation by Rumen Microorganisms and Gastro intestinal Proteases. J. Anim. Sci., 74, 1621-1630. https://doi.org/10.2527/2001.7961621x

Mathlouthi, N., Juin, H., \& Larbier, M. (2003). Effect of Xylanase and beta-glucanase supplementation of wheat based diets on the performance of male turkeys. Br. Poult. Sci., 44, 291-298. https://doi.org/10.1080/ 0007166031000096498

Mathlouthi, N., Lalles, J. P., Lepercq, P., Juste, C., \& Larbier, M. (2002). Xylanase and B-glucanase supplementation improve conjugated bile acid fraction in intestinal contents and increase villus size of small intestine wall in broiler chickens fed rye based diet. J. Anim. Sci., 80, 2773-2779. https://doi.org/ $10.2527 / 2002.80112773 x$

Meera, R., Devi, P., Kameswari, B., Madhumitha, B., \& Merlin, N. J. (2009). Antioxidant and hepatoprotective activities of Ocimum basillicumlinn and Trigonella foenumgroecum Linn against $\mathrm{H}_{2} \mathrm{O}_{2}$ and $\mathrm{CCl}_{4}$ induced hepatotoxicity in goat liver. Indian J. Exp. Biol., 47, 584-590. 
Montague, L., Plusje, J. R., \& Hampson D. J. (2003). A review of interaction between dietary fiber and intestinal mucosa and their consequences on digestive health in young non ruminant animals. Anim. Feed .Sci. Technol., 108, 95-117. https://doi.org/10.1016/S0377-8401(03)00163-9

Mousa, A. S. (2008). physiological studies on the effects of some feed additives on some metabolic and Haemostatic parameters in broilers ( $\mathrm{PhD}$ thesis, Cairo University, Egypt).

National Research Council (NRC). (1994). Nutrient requirement of poultry (9th ed.). National Academy of Science, Washington, DC.

Neto, R. M., Ceccanlin, M. L., \& Ferm\&es, J. I. (2012). Productive Performance, intestinal morphology and carcass yield of broilers fed conventional and alternative diets containing commercial enzymatic complex. International Journal of Poultry Science, 11(8), 505-516. https://doi.org/10.3923/ijps.2012.505.516

Nishikimi, M., Roa, N. A., \& Yogi, K. (1972). The occurrence of superoxide anion in the reaction of reduced phenazinemethosulphate and molecular oxygen. Biochem. Bioph. Res. Common., 46, 849-854. https://doi.org/10.1016/S0006-291X(72)80218-3

Ocak, N., Erener, G., Burak, F., Sungu, M., Altop, A., \& Ozmen, A. (2008). Performance of broilers fed diets supplemented with dry peppermint (Mentha piperita L.) or thyme (Thymus vulgaris L.) leaves as growth promoter source. Czech Journal of Animal Science, 53(4), 169-175.

Odetallah, N. H., Ferket, P. R., Grimes, J. L., \& Menaughton, J. L. (2002). Effect of Mannan-endo1,4-beta-mannosidase on the growth performance of turkeys fed diets containing 44 and $48 \%$ crude protein soybean meal. Poult. Sci., 81, 1322-31. https://doi.org/10.1093/ps/81.9.1322

Ohkawa, H., Ohishi, W., \& Yagi, K. (1979). Assay for lipid peroxides in animal tissues by thiobarbituric acid reaction. Anal Biochem, 95, 351. https://doi.org/10.1016/0003-2697(79)90738-3

Olukosi, O. A., Cowieson, A. J., \& Adeola, O. (2007). Age-related influence of a cocktail of xylanase, amylase and protease or phytase individually or in combination in broilers. Poultry Science, 86, 77-86. https://doi.org/10.1093/ps/86.1.77

Osman, M., Yakout, H. M., Motawe, H. F., \& Ezz El-Arab, W. F. (2010). Productive, physiological, immunological and economical effects of supplementing natural feed additives to broiler diets, Egypt. Poult. Sci., 30, 25-53.

Osman, N., Talat, G., Medmet, C., \& Bestami, D. (2005). Effect of an essential oil mix derived from oregano, clove and aniseed on broiler performance. Int. J. Poul. Sci., 4, 879-884. https://doi.org/10.3923/ijps.2005. 879.884

Peric, L., Milosevic, N., Ziki, D., Bjedov, S., Cvetcovic, D., Markov, S., ... Steimer, T. (2010). Effects of probiotic and phytogenic products on performance, gut morophology and cecal microflora of broiler chickens. Archive Tierzucht, 53(3), 350-359.

Pluske, J. R., Sba, P. M., Pethick, D. W., Durmic, Z., Mullan, B. P., \& Hampson, D. J. (1996). The incidence of swine dysentery in pigs can be reduced by feeding diets that limit the amount of fermentable substrate entering large intestine. J. Nutri., 26(11), 2920-2933.

Prescott, N. B., Wathes, C. M., \& Jarvis, J. R. (2003). Light, vision and the welfare of poultry. Anim. Welf., 12, 269-288.

Rahim, A., Mirza Aghazadeh, A., \& Daneshyar, M. (2011). Growth performance and some carcass characteristics in broiler chickens supplemented with Thymus extract (Thymus vulgaris) in drinking water. $J$. Am. Sci., 7(11), 400-405.

Saleh, F. M., Yamamoto, M. A., Tahrir, A., Ohtsuka, A., \& Hayashi, K. (2006). A new natural feed additive for broiler chicken (pp. 36-54). Poult. Sci. Asso. Annual Meetings, Edomonton, Canada.

Saleh, S. Y., Ahia, K. A., Rsawiress, F. A., Zaki, A. A., \& Nassar, M. M. (2008). Alterations of some Hemostatic parameters of Turkey toms supplemented with multiemzyme feed additive. In 7th International Symposium on Turkey Clisease, Berlin, 19-21 June.

Saleh, S. Y., Attia, K. A., Manal, A. F., \& Nassar, M. M. (2010). Effects of multi-enzyme feed additive "kemzyme" or/and sodium bentonite "as a feed binder"on sexual activity and some fertility parameters of bucks. Journal of Agricultural Science, 2(4), 89-99. https://doi.org/10.5539/jas.v2n4p89 
Santos Jr, A. A., Ferket, P. R., Grimes, J. L., \& Edens, F. W. (2004). Dietary supplementation of endoxylanases and phospholipase for turkeys fed wheat based ration. Int. J. Poult. Sci, 3, 20-23. https://oi.org/10.3923/ ijps.2004.20.32

Schiavone, A., Righi, F., Quarantelli, A., Brun, R., Serventi, P., \& Fusari, A. (2007). Use of Sibyllum marianum fruit extract in broiler chicken nutrition: Influence on performance and meat quality. J. Anim. Physiol. Anim. Nutr., 91, 256-267. https://doi.org/10.1111/j.1439-0396.2007.00701.x

Schwartiz, K., Ernst, H., \& Ternes, W. (1996). Evaluation of antioxidant constituents from thyme. Journal of the Science of Food Agriculture, 70, 217-223. https://doi.org/10.1002/(SICI)1097-0010(199602)70:2\%3C217:: AID-JSFA488\%3E3.0.CO;2-Y

Sengül, T., Yurtseven, S., Cetin, M., Kocyigit, A., \& Sögüt, B. (2008). Effect of thyme (T. vulgaris) extracts on fattening performance, some blood parameters, oxidativestress and DNA damage in Japanese quails. Journal of Animal and Feed Science, 17, 608-620. https://doi.org/10.22358/jafs/66689/2008

Seung-Jool, L., Katumi, U., Takayuki, S., \& Kwang-Geun, L. (2005). Identification of volatile components in basil (Ocimum basilicum L.) and thyme leaves (Thymus vulgaris L.) and their antioxidant properties. Food Chemistry, 91, 131-137. https://doi.org/10.1016/j.foodchem.2004.05.056

Shams Sharph, M., Bastar, B., Zerehddaran, S., Khomeiri, M., \& Maradi, A. (2012). Effects of using plant extracts and a probiotic on performance, intestinal morphology and microflora population in broilers. $J$. Appl. Poult. Res., 21, 201-208. https://doi.org/10.3382/japr.2010-00145

Sharifi, S. D., Khorsandi, S. H., Khadem, A. A., Salehi, A., \& Moslehi, H. (2013). The effect of four medicinal plants on the performance, blood biochemical traits and ileal microflora of broiler chicks. Veterinarski Archiv., 83(1), 69-80.

Sharma, R., \& Kaur, S. (2015). Comparative Analysis of Phenolic Content and Anti-oxidant Activity of Dietary Vegetables. Bioscience Methods, 6(2), 1-7. https://doi.org/10.5376/bm.2015.06.0002

Snedcor, G. M., \& Cochran, W. G. (1980). Statistical analysis (7th ed., pp. 215-237).

Taylor-Pickard, J. A., \& Spring, P. (2008). Gut efficiency: The key ingredient in pig and poultry production (p. 189). Wageningen Academic Publishers. https://doi.org/10.3920/978-90-8686-636-6

Toghyani, M., Tohidi, M., Gheisari, A. A., \& Tabei-Dian, S. A. (2010). Performance, immunity, serum biochemical and hematological parameters in broiler chicks fed dietary thyme as alternative for an antibiotic growth promoter. Afr. J. Biotechnol., 9, 6819-6825.

Tucker, L. (2002). Botanical broilers: Plant extracts to maintain poultry performance. Feed Int., 23, 26-29.

Uni, Z. Noy, Y., \& Sklan, D. (1996). Development of small intestine in heavy and light chicks before and after hatching. Br. Sci., 37, 63-71. https://doi.org/10.1080/00071669608417837

Uni, Z., \& Sklan, D. (1999). Functional development of the small intestine: Cellular and molecular aspects. Proceedings of the 12th European Symposium on Poultry Nutrition (pp. 171-176). Dutch Branch World Poultry Science Association, Veldhoven, The Netherlands.

Uni, Z., Ganot, S., \& Sklan, D. (1998). Posthatch development of mucosal function in the broiler small intestine. Poult. Sci., 77, 75-82. https://doi.org/10.1093/ps/77.1.75

Uni, Z., Noy, Y., \& Sklan, D. (1995). Post hatchchanges in morphology and function of the small intestine in heavy and light strain chicks. Poult. Sci., 74, 1622-1629. https://doi.org/10.3382/ps.0741622

Wenk, C. (2000). Why all the discussion about herbs? In T. P. Lyons (Ed.), Proc. Alltech, 16th Ann. Symp. Biotechnol. in the Feed Industry (pp. 79-96). Alltech Tech. Publ., Nottingham, University Press, Nicholasville, KY.

Xu, Z. R., Hu, C. H., Xia, M. S., Zhan, X. A., \& Wang, M. Q. (2003). Effect of dietary fructooligo saccharide on digestive enzyme activities, intestinal microflora and morphology of male broilers. Poult. Sci., 82, 648-654. https://doi.org/10.1093/ps/82.6.1030

Yahav, S., Plavnik, I., Rusal, M., \& Hurwitz, S. (1998). Response of turkeys to relative humidity at high ambient temperature. Br. Poult. Sci., 39, 340-345. https://doi.org/10.1080/00071669888872

Yanishlieva, N. M., Marinova, E. M., Gordon, M. H., \& Raneva, V. G. (1999). Antioxidant activity and mechanisms of action of thymol and carvacrol in two lipid systems. Food Chem., 64, 59-66. https://doi.org/10.1016/S0308-8146(98)00086-7 
Zakaria, H. A. H., Jalal, M. A. R., \& Abu-Ishmais, M. A. (2010). The influence of supplemental multi-enzyme feed additive on performance, carcass characteristics and meat quality traits of broiler chicken. Int. J. Poult. Sci., 9(2), 126-133. https://doi.org/10.3923/ijps.2010.126.133

Zhang, J. W., Li, S. K., \& Wu, W. J. (2009). The main chemical composition and vitro antifungal activity of the essential oils of Ocimum basillicum Linn.Var. pilosum Benth. Mollleciles, 14, 273-278. https://doi.org/ 10.3390/molecules14010273

Zheng, W., \& Wang, S. Y. (2001). Antioxidant activity of phenolic compounds in selected herbs. J. Agric. Food Chem., 49, 5165-5170. https://doi.org/10.1021/jf010697n

Zhou, Y., Jiang, Z., Ly, D., \& Wang, T. (2009). Improved energy-utilizing efficiency by enzyme preparation supplemented in broiler diets with different metabolizable energy levels. Poult. Sci., 88, 316-322. https://doi.org/10.3382/ps.2008-00231

Zijstra, R. T., Delange, C. F., \& Patience, J. F. (1999). Nutritional value of wheat for growing pigs chemical composition and digestable energy content. Can. J. Anim. Sci., 79, 187-194. https://doi.org/10.4141/ A98-103

Zikic, D., Peric, L., Uscebrka, G., Stojanovic, S., Milic, D., \& Noller, L. (2008). Effect of prebiotics in broiler breeder and broiler diets on performance and Jeujenum morphology of broiler chickens (pp. 879-882). $1^{\text {st }}$ Mediteranean summit of WPSA, Book of Proceedings, Porto Carna, Greece.

Zollner, N., \& Kirsch, K. (1962). Uber Die Quantitative Bestimmung von Lipoiden (Mikromethode) Mittels der Vielen Natiirlichen Lipoiden (Allen bekannten Plasmalipoiden) Gemeinsamen Sulphophosphovanillin Reaktion. Zges. Exp. Med., 135, 545-56. https://doi.org/10.1007/BF02045455

\section{Copyrights}

Copyright for this article is retained by the author(s), with first publication rights granted to the journal.

This is an open-access article distributed under the terms and conditions of the Creative Commons Attribution license (http://creativecommons.org/licenses/by/4.0/). 